\title{
Presence of non-oral bacteria in the oral cavity
}

\author{
Nawel Zaatout ${ }^{1}[$ \\ Received: 24 September 2020 / Revised: 20 November 2020 / Accepted: 22 March 2021 / Published online: 31 March 2021 \\ (c) The Author(s), under exclusive licence to Springer-Verlag GmbH Germany, part of Springer Nature 2021
}

\begin{abstract}
A homeostatic balance exists between the resident microbiota in the oral cavity and the host. Perturbations of the oral microbiota under particular conditions can contribute to the growth of non-oral pathogens that are hard to kill because of their higher resistance to antimicrobials, raising the probability of treatment failure and reinfection. The presence of these bacteria in the oral cavity has been proven to be associated with several oral diseases such as periodontitis, caries, and gingivitis, and systemic diseases of importance in clinical medicine such as cystic fibrosis, HIV, and rheumatoid arthritis. However, it is still controversial whether these species are merely transient members or unique to the oral cavity. Mutualistic and antagonistic interactions between the oral microbiota and non-oral pathogens can also occur, though the mechanisms used by these bacteria are not clear. Therefore, this review presents an overview of the current knowledge about the presence of non-oral bacteria in the oral cavity, their relationship with systemic and oral diseases, and their interactions with oral bacteria.
\end{abstract}

Keywords Oral microbiota $\cdot$ Non-oral bacteria $\cdot$ Periodontitis $\cdot$ Systemic diseases

\section{Introduction}

The oral cavity is a complex and dynamic environment and is the primary gateway to the human body (Zarco et al. 2012; Craig et al. 2018). Various studies have identified over 1000 species from the oral cavity that forms the oral microbiota (Mahasneh et al. 2017; Gao et al. 2018). However, only a tiny fraction is causing oral infections such as dental caries and periodontitis (Kreth and Merritt 2009; Dewhirst et al. 2010). An imbalance of microbial flora contributes to the growth of various clinically important pathogens, that are generally considered "non-oral" bacteria, such as Gramnegative enteric rods (GNRs), enterococci, and staphylococci (Al-Ahmad et al. 2009; Van Winkelhoff et al. 2016). Non-oral bacteria are non-resident, super-infectious microorganisms that are not generally considered a common part of the oral microbiota. Their eradication from the dental biofilms seems to be more challenging due to their higher resistance to antimicrobials, raising the probability of treatment

Communicated by Erko Stackebrandt.

Nawel Zaatout

Zaatout5@hotmail.com

1 Faculty of Natural and Life Sciences, University of Batna 2, 05000 Batna, Algeria failure and reinfection (Souto et al. 2006). There has been a great deal of confusion in the literature regarding their natural reservoir and their ability to colonize the oral cavity. Previous studies have revealed that they may occur in high numbers and shift from transitory species to colonizers of the oral cavity in immunocompromised individuals (SimõesSilva et al. 2018; Arirachakaran et al. 2019). However, some studies have shown that they can colonize healthy subjects too (Ranganathan et al. 2017; Chinnasamy et al. 2019). Moreover, systemic colonization and infections associated with non-oral bacteria isolated from the oral cavity have been revealed (Arirachakaran et al. 2019; Ghapanchi et al. 2019), making the oral cavity an extra-hospital reservoir (Kearney et al. 2020).

Currently, there are a limited understanding and limited information regarding the pathogenesis of non-oral bacteria in the oral cavity. To the best of our knowledge, there are no reviews on the role of non-oral bacteria in the oral cavity and their relationship with the oral microbiota. Therefore, this review examines the current knowledge about the most extensively studied non-oral bacteria in the oral cavity and also provides an overview of the interactions between the oral microbiota and non-oral bacteria. 


\section{Non-oral bacteria in the oral cavity: transitory species or colonizers?}

Non-oral bacteria are commonly found in other parts of the human body (nares or gut). They can accidentally be introduced into the mouth by food, water, contact with animals, mouthing and chewing items, etc. Nevertheless, nowadays, there is a controversy about whether the oral cavity is an entry point or an important reservoir for this group of bacteria and whether they are merely transient or unique to this niche (Zuanazzi et al. 2010; Vieira Colombo et al. 2016).

There has been strong evidence that they might colonize the oral ecosystem (Souto and Colombo 2008a; Gonçalves et al. 2007a; Da Silva-Boghossian et al. 2011). Patients positive with certain subgingival non-oral species, most notably Acinetobacter baumannii and Pseudomonas aeruginosa, are reported to show a higher percentage of periodontal sites with suppuration on probing (Silva-Boghossian et al. 2013), greater periodontal attachment loss (Da Silva-Boghossian et al. 2013; Van Winkelhoff et al. 2016) and much more aggressive forms of periodontitis. Furthermore, some of these bacteria isolated from the oral cavity, such as enterococci, were found to be genetically different from isolates from other parts of the human body (Vidana et al. 2011), which could potentially lead to another understanding of the ecosystem of the oral cavity.

The disturbance of the "equilibrium" (due to medical treatments, biological changes, or inadequate hygiene) between commensal bacteria and the host immune system could be the reason for the shift of non-oral bacteria from transitory species to colonizers (Handal et al. 2003; Dahlen 2009; Tada and Hanada 2010), and could enhance the subsequent morbid microbial communities in the compromised host (Botero et al. 2007a; Vieira Colombo et al. 2016). However, in normal oral health conditions, one should not expect these microorganisms to overcome in proportions the very well adapted oral species (Van Winkelhoff et al. 2016).

The most extensively studied species in the oral cavity are species of Enterobacteriaceae, Staphylococcus aureus, Enterococcus faecalis, Pseudomonas aeruginosa, and Acinetobacter baumannii. The presence of unique and specific virulence factors can help in distinguishing between these different species.

\section{Enterobacteriaceae}

Enterobacteriaceae is a family of Gram-negative rods that have stood out in the healthcare environment due to the variety of severe infections that they can cause and their resistance to antibiotics (Leão-Vasconcelos et al. 2015). Their presence in the oral ecosystem is perhaps due to the ingestion of contaminated drinking water, food or poor personal hygiene (Barbosa et al. 2001; Gonçalves et al. 2007b). The prevalence of GNRs in the oral environment is extremely variable, and it is still not clear whether they are colonizing or merely transient bacteria. This is probably due to the use of single-sample techniques that do not allow the differentiation between transient presence and persistent presence (Martinez-Pabon et al. 2010). However, it has been shown that the prolonged transportation time of the samples may encourage the multiplication of GNRs, leading to higher positive results (Ali et al. 1996).

Moreover, numerous studies on GNRs pathogenesis in the oral ecosystem have shown that (1) they can persist within the subgingival environment after periodontal debridement and surgery (Slots et al. 1991), (2) they are implicated as key pathogens in cases of refractory periodontitis (Edwardsson et al. 1999), (3) they are detected at greater frequency and in higher proportions in patients with failing implants (Listgarten et al. 1999) and (4) they are usually associated with oral mucosal infections in immune-compromised patients. In these patients, oral mucosal infections may spread to the respiratory system and trigger life-threatening infections (Scannapecio et al. 2009; Tada and Hanada 2010). Furthermore, their virulence factors are conferred through several properties that give the ability to adhere and invade the host's tissues (Kazemian et al. 2017). Such as the release of enterotoxins and endotoxins, elaboration of extracellular leukotoxins, degradation of immunoglobulins IgG and IgA, suppression of lymphocyte proliferation and elaboration of collagenolytic and other proteolytic enzymes (Barbosa et al. 2001). Nevertheless, the GNRs are rarely identified at the species level, and they are referred to as "enterics" (Martinez-Pabón et al. 2010). However, the group is made up of a wide variety of bacterial species, which are incongruent in pathogenicity, virulence and antibiotic susceptibility (Arirachakaran et al. 2019). At the species level, some authors have found that some Gram-negative rods can dominate among oral species in some cases, like Pereira et al. (2013) who found that K. pneumoniae is the dominant bacterial species in cases wearing removable maxillary prosthesis with and without denture stomatitis lesions. Also, according to Zhu et al. (2008), there exists an important correlation between the presence of $K$. pneumoniae in the oral cavity and the risk of pneumonia by aspiration of these bacteria in people suffering from a stroke.

Moreover, its ability to degrade elastin (which is perceived to be a marker of $P$. aeruginosa in the aetiology of lower respiratory tract infections (Beatty et al. 2005)) could contribute to its virulence (Goncalve et al. 2007). Thurnheer and Belibasakis (2015) observed that when Escherichia coli are given the appropriate nutritional and environmental 
conditions, they can endure and even dominate among oral species in a polymicrobial biofilm. However, Back-Brito et al. (2011) have found considerably higher numbers of enteric bacteria in the oral cavities of HIV-positive patients, and Enterobacter cloacae were the most frequently isolated species (Table 1, the search strategy is in the supplementary file, Table S1). Interestingly, it was found that the presence of Candida albicans in the oral cavity can increase the growth and the swarming activity of Proteus mirabilis (Kart et al. 2020).

\section{Staphylococcus aureus}

Although the anterior nares are considered the primary ecological niche for Staphylococcus (Kearney et al. 2020), their presence in the oral cavity is unquestionable (Soni et al. 2017) but controversial (Smith et al. 2001), as it is not clear whether they play a part in the ecology of the healthy oral flora or not (Smith et al. 2003a; Blomqvist et al. 2015).

However, many authors have indicated that the oral cavity functions as a potential reservoir for $S$. aureus infections in immunosuppressed patients (Agwu et al. 2015; Merghni et al. 2015) (Table 1) and might cause some oral diseases such as periodontitis and dental caries (Fritschi et al. 2008; Merghni et al. 2014); and systemic diseases such as heart disease, chronic kidney disease, orofacial granulomatosis and Crohn's disease (Gibson et al. 2000; Zuanazzi et al. 2010; Simões-Silva et al. 2018). Oral S. aureus has also been recognized as an aetiological factor of infective endocarditis (Carmona et al. 2002).

Persson and Renvert (2014) found that $S$. aureus is present at higher amounts in biofilms obtained from implants with peri-implantitis than peri-implant healthy subjects. Other studies have revealed that $S$. aureus was found at higher levels in the oral cavity and with greater prevalence in periodontitis than non-periodontitis subjects (Souto et al. 2006; Persson et al. 2008), while Fritschi et al. (2008) found higher levels of $S$. aureus in aggressive than chronic periodontitis subjects. Consequently, S. aureus was pointed out as a contributor to the microbial profiles that could differentiate between aggressive and chronic forms of the disease. Moreover, S. aureus was found at higher levels in the oral cavity of patients with rheumatoid arthritis than healthy controls (Jackson et al. 1999) and was the most frequently isolated species in the oral cavities of HIV-positive patients (Back-Brito et al. 2011). The ability of $S$. aureus to cause such a diverse array of problems is due to its arsenal of virulence factors that are coordinately expressed during different stages of infection, such as superantigens, toxins such as $\beta$-toxin, matrix-binding surface adhesins, biofilm formation and tissue-degrading enzymes such as proteases, lipases, nucleases, and collagenases (Lowy 1998; Merghni et al. 2014; Lima et al. 2019).

\section{Enterococcus faecalis}

E. faecalis is not yet considered a normal inhabitant of the oral cavity (Kouidhi et al. 2011) but has been isolated from various oral conditions, including periodontitis and dental caries (Zhu et al. 2010; Kouidhi et al. 2011) (Table 1). It is perceived to be the predominant infectious agent associated with primary and secondary endodontic infections (Vidana et al. 2011) because of its ability to reside within different layers of the oral biofilm, and co-aggregate with different saliva bacteria, which leads to failure of endodontic therapy (Al-Ahmad et al. 2010).

Moreover, it has been found that E. faecalis can preserve viability in root canals ex vivo for at least 12 months (Sedgley et al. 2005); this is perhaps due to its ability to form biofilms (Al-Ahmad et al. 2009, 2014) or colonize multi-species supragingival biofilms (Thurnheer and Belibasakis 2015). Furthermore, coexistence between enterococci and C. albicans has been observed in immunocompromised patients (Almståhl et al. 2001, 2008).

The origin of these opportunistic bacteria in the oral cavity is not yet clear. Wang et al. (2011) demonstrated that the prevalence of E. faecalis in the root canal system had been correlated with its occurrence in saliva. Meanwhile, some authors suggested nosocomial transmission from environmental surfaces in dental surgeries due to the robust nature of the microorganisms (Vidana et al. 2011; Lins et al. 2019), while others proposed foodborne transmission (Zehnder and Guggenheim 2009). However, Vidana et al. (2011) examined the genetic relationship between $E$. faecalis from root canals and isolates from different host sources and found that isolates from the root canals were not related to those from the typical gastrointestinal microflora, and none of these patients was recorded to have enterococci in their saliva. Likewise, Cole et al. (1999) did not find any members of this species in the saliva probes from 10 infants. Further investigations are needed to minimize the dissemination of virulent and multidrug-resistant clones to the oral cavity. In addition to their role in oral diseases, subsequent systemic colonization and infection associated with an oral source of enterococci have been found; Okui et al. (2015) reported a case of infective endocarditis of oral origin caused by $E$. faecalis, while Arirachakaran et al. (2016) isolated oral enterococci from HIV patients.

The most studied virulence factors of $E$. faecalis include biofilms, aggregation substance, gelatinase, lipoteichoic acid, the cytolysin toxin, surface adhesins, extracellular superoxide, sex pheromones, and hyaluronidase. Each of these factors might be associated with many phases of endodontic infections, periapical inflammation, and systemic diseases (Kayaoglu and Ørstavik 2004; Anderson et al. 2016; Komiyama et al. 2016). 


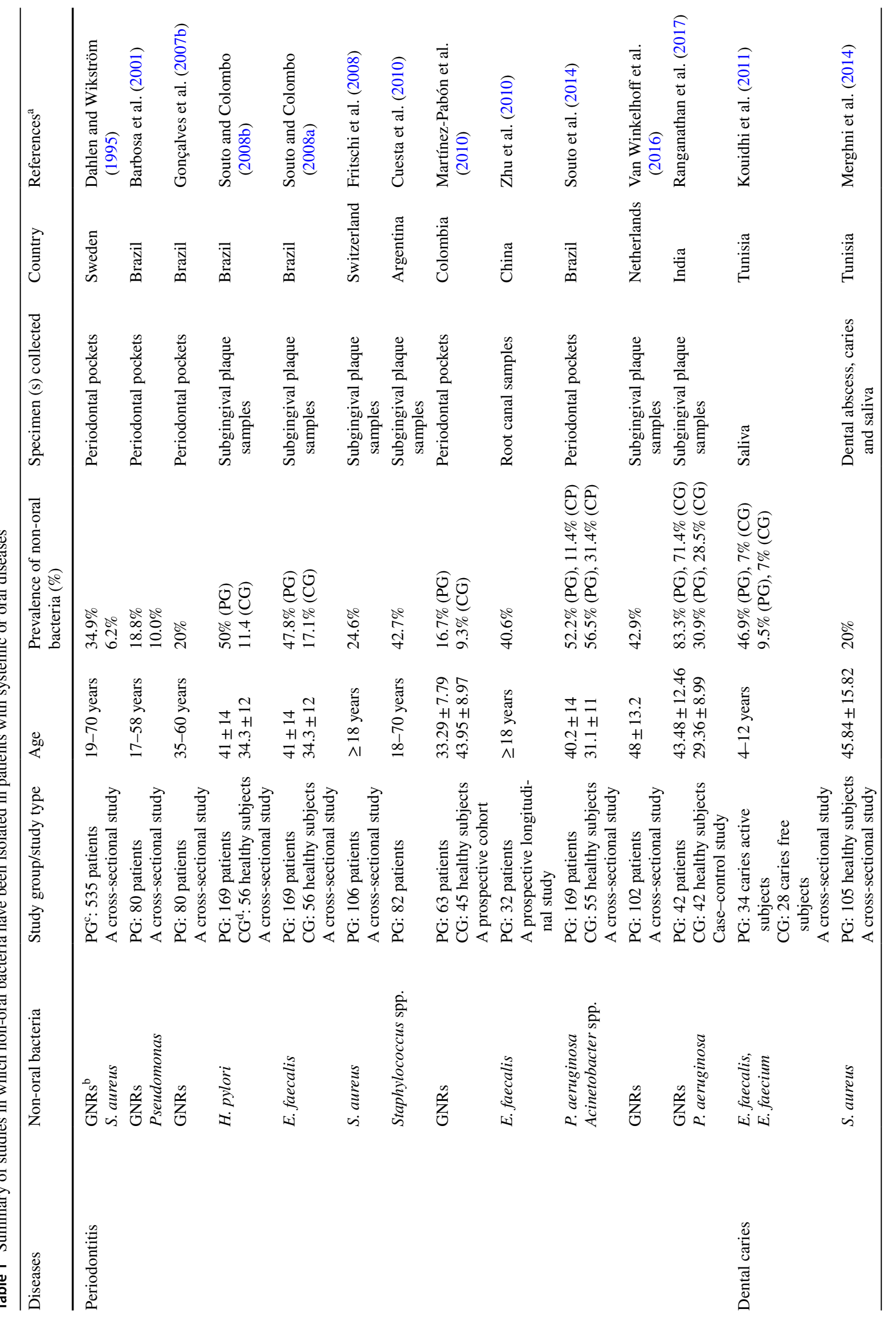




\begin{tabular}{|c|c|c|c|c|c|c|c|c|}
\hline 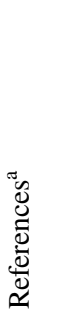 & 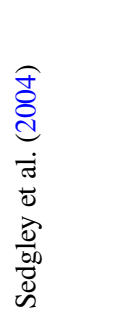 & 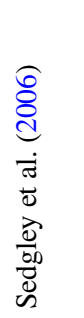 & 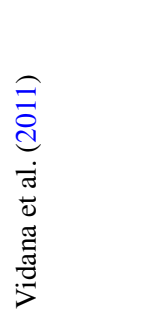 & 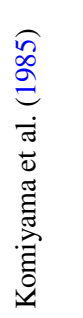 & 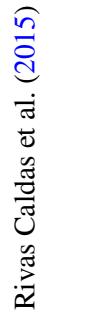 & 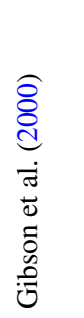 & 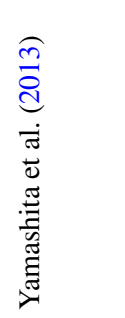 & 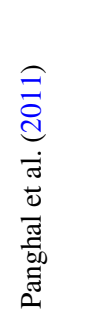 \\
\hline$\vec{\Xi}$ & 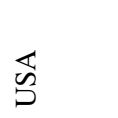 & 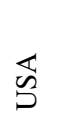 & 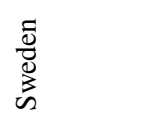 & 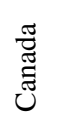 & 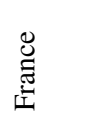 & 光 & $\begin{array}{l}\text { E్ } \\
\text { ב్̃ }\end{array}$ & $\stackrel{g}{g}$ \\
\hline 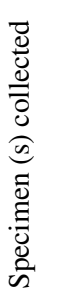 & 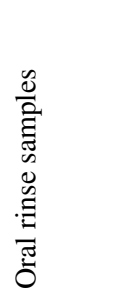 & 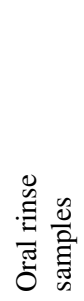 & 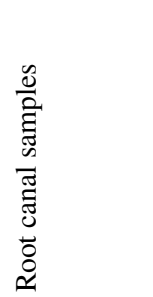 & 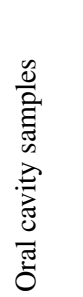 & 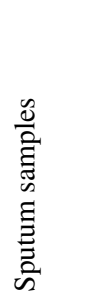 & 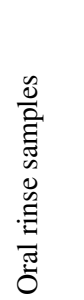 & 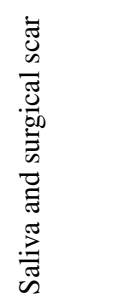 & 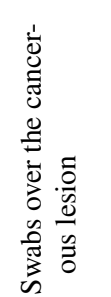 \\
\hline 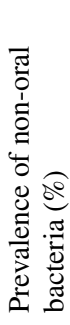 & $\begin{array}{l}\hat{0} 00 \\
\stackrel{0}{0} \\
00 \\
=\end{array}$ & ஃ̊ & 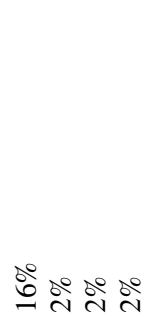 & 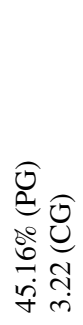 & 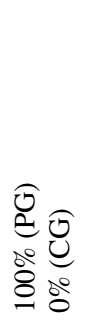 & $\begin{array}{l}\infty \\
\infty \\
0 \\
0\end{array}$ & 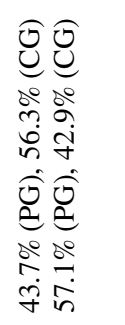 & 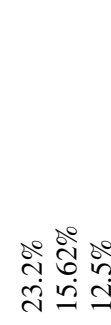 \\
\hline$\stackrel{8}{4}$ & 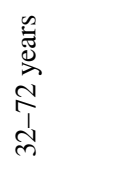 & $\begin{array}{l}m \\
m \\
n \\
+1 \\
0 \\
\stackrel{y}{y}\end{array}$ & 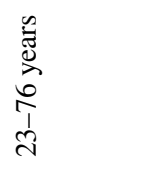 & $\begin{array}{l}\text { 节 } \\
\text { ते } \\
\text { ì }\end{array}$ & 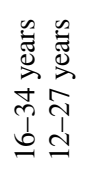 & 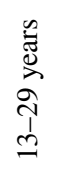 & 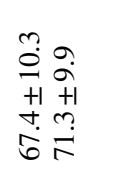 & \\
\hline 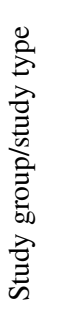 & 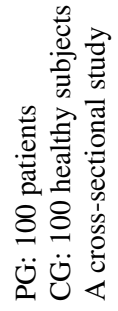 & 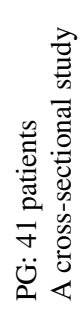 & 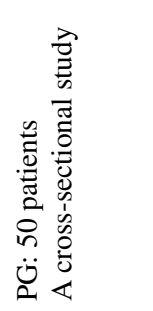 & 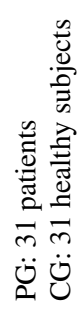 & 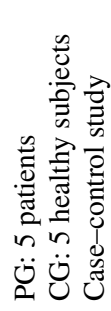 & 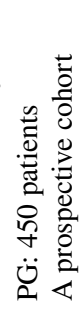 & 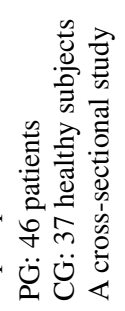 & 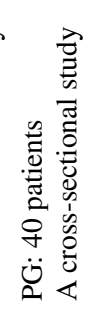 \\
\hline 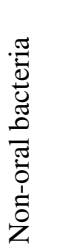 & 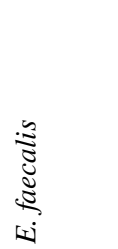 & 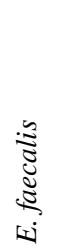 & 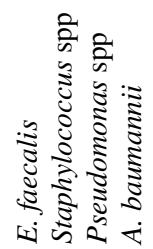 & 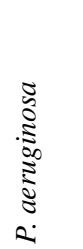 & 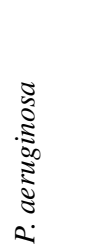 & $\begin{array}{l}\tilde{\Xi} \\
\stackrel{\Xi}{5} \\
\dot{\omega}\end{array}$ & 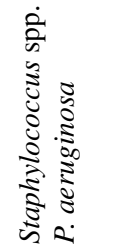 & 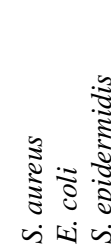 \\
\hline $\begin{array}{l}\mathscr{0} \\
\tilde{w} \\
0 \\
\infty\end{array}$ & 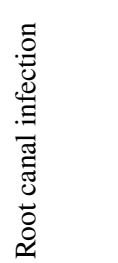 & & & 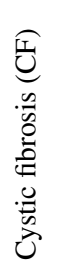 & & 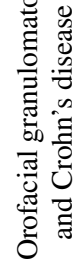 & 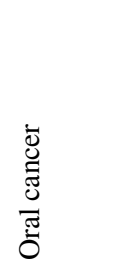 & \\
\hline
\end{tabular}




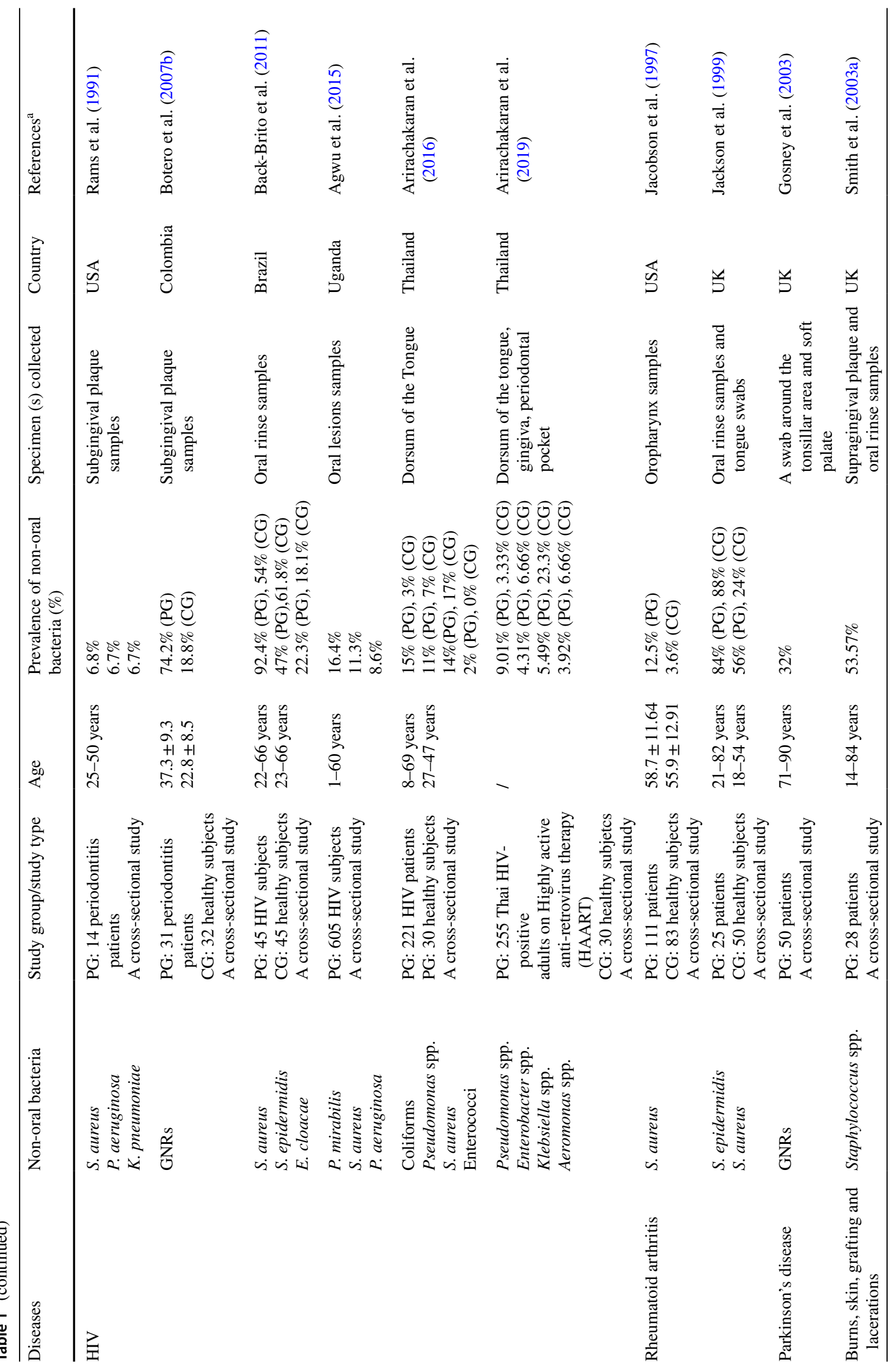




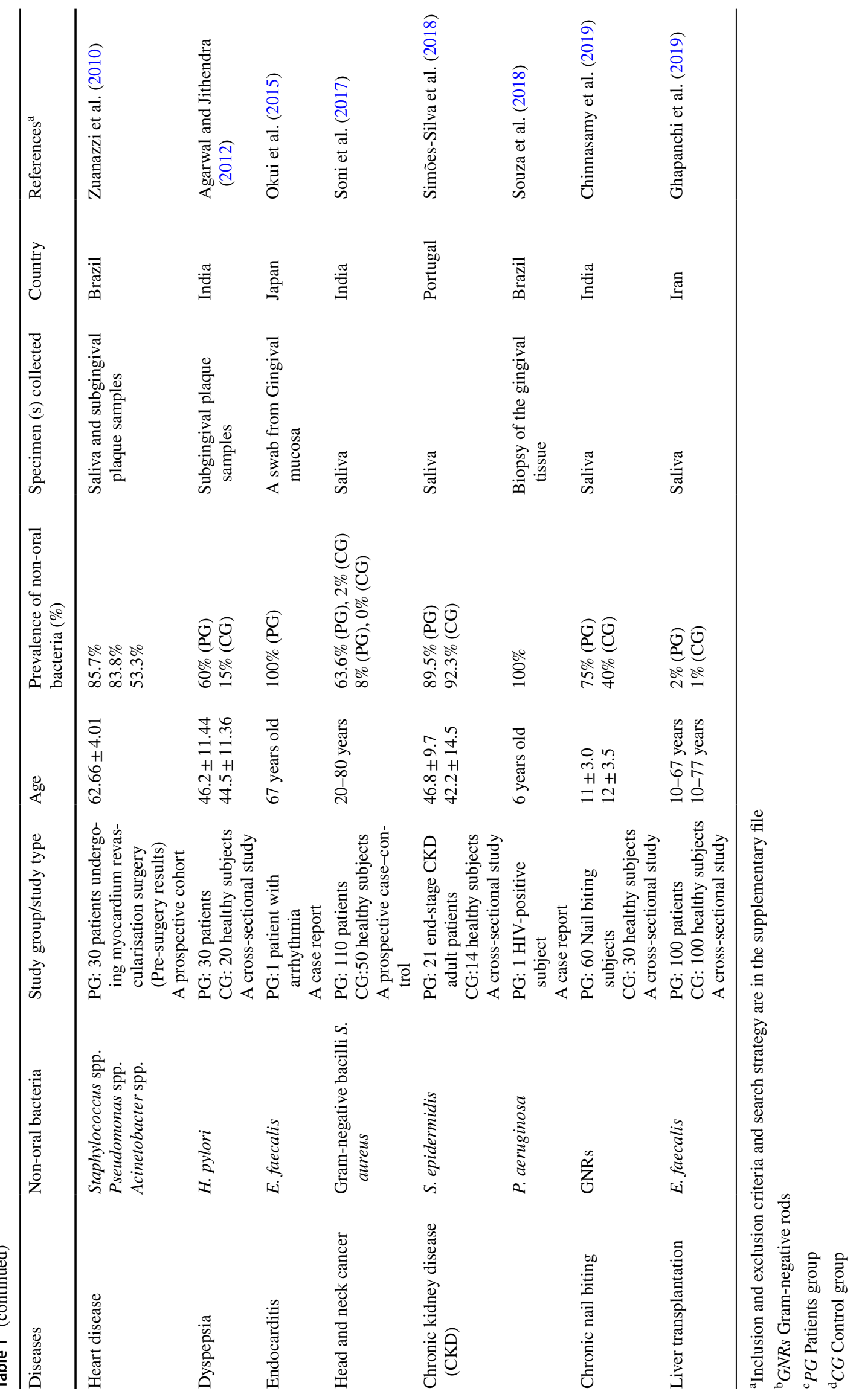




\section{Pseudomonas aeruginosa}

Pseudomonas aeruginosa is a Gram-negative bacillus that most often affects the lower respiratory system and is associated with nosocomial infections (Watanabe et al. 2009). It can be part of the transient oral microbiota but seldom colonize the oral cavity, which is perhaps due to its strong aerobic character (Arirachakaran et al. 2019). However, studies using molecular biology methods have revealed that its presence in the oral cavity is underestimated and it is much higher in complex biofilms (Wade 2013; Souza et al. 2018).

Moreover, these species have many virulence properties such as the ability to adhere to and form biofilms on tissues and abiotic surfaces (Smith and Iglewski 2003b), along with their ability to produce and secrete extracellular enzymes and toxins (Smith and Iglewski 2003b; Pihl et al. 2010) as well as the expression of multiple antimicrobial resistance elements (Livermore 2002). P. aeruginosa has also been identified in the periodontal pockets of immunocompromised subjects (Nakou et al. 1997) and might be an important pathogen in periodontitis and gingivitis (Persson et al. 2008; Vieira Colombo et al. 2016) (Table 1).

Moreover, they are perceived to be the main pathogen in chronic obstructive pulmonary disease and biofilms on vehicles at intubation (Ewan et al. 2015). Their passage into the lungs may occur by passive aspiration of the bacterial microbiota released in saliva or eased by medical devices such as bronchoscopes and endotracheal tubes (Scannapieco et al. 2009). Lately, oral $P$. aeruginosa has been associated with oral squamous cell carcinoma (Al-Hebshi et al. 2017) and chronic kidney disease (Simões-Silva et al. 2018). Additionally, focal necrotizing lesions have been found in the oral mucosa of HIV-positive patients, which are different from periodontal disease patterns and are related to the presence of oral P. aeruginosa (Souza et al. 2018).

\section{Acinetobacter baumannii}

A. baumannii is a Gram-negative bacillus often found in the hospital environment. It is among the red list group of ESKAPE pathogens (E. faecium, S. aureus, K. pneumoniae, A. baumannii, P. aeruginosa, and Enterobacter species) announced as a critical priority pathogen by World Health Organization (WHO) (WHO 2017).

There are not many reports on the incidence of $A$. baumannii in the oral cavity or its association with oral diseases; though some studies have found that it is significantly associated with suppuration in chronic periodontitis patients, aggressive periodontitis and root canal infections (Da SilvaBoghossian et al. 2013; Vidana et al. 2011; Souto et al. 2014), especially in patients with human immunodeficiency virus (Gonçalves et al. 2007a). Also, the likelihood of a subject being refractory to periodontal treatment increases when
A. baumannii is present (Colombo et al. 1998). Furthermore, it is a major pathogen in ventilator-associated pneumonia, which is a massive problem in hospitals, particularly in intensive care units (Lee et al. 2012; Martinez-Lamas et al. 2014), and was isolated from patients suffering from heart disease (Zuanazzi et al. 2010).

Major virulence factors that were studied in A. baumannii isolated from the oral cavity are lipocalins production, biofilm formation, siderophore-mediated iron-acquisition system, outer membrane protein A, desiccation resistance and the ability to bypass the glucose metabolism, which can be considered as one of the key factors that help this bacteria survive in a nutrition-deficient environment (Richards et al. 2015; Priyadharsini et al. 2018).

\section{Interactions between the oral microbiota and non-oral bacteria}

In the oral cavity, where resources are limited, collaborations between species are needed to survive and endure. Some studies have shown the physical and metabolic interactions that exist between members of the oral microbiota and nonoral species; they can be mutualistic interspecies interactions (coaggregation) to form biofilms or antagonistic interactions to prevent the integration of a non indigenous bacterial species (Table 2). However, the biological mechanisms underlying these interactions are not yet clear.

Coaggregation is defined as cell-to-cell adhesion in which cells of a species adhere more or less specifically to different species (Kolenbrande 2000). This mechanism is involved in the establishment and maintenance of biofilms (Kolenbrander et al. 2010). For instance, in periodontitis patients, an association was found between GNRs and Porphyromonas gingivalis with Tannerella forsythia; both members of the "red complex" bacterial species are associated with severe forms of periodontitis (Socransky et al. 1998). Ardila et al. (2011, 2012) also reported a positive subgingival correlation between GNRs and $P$. gingivalis, and between GNRs and Aggregatibacter actinomycetemcomitans. Likewise, E. faecalis strains coaggregated with Fusobacterium nucleatum (Johnson et al. 2006), which was able to co-aggregate with Helicobacter pylori (Andersen et al. 1998) and S. aureus (Tawara et al. 1996; Lima et al. 2019). Fusobacterium is considered a key microorganism in the process of coaggregation among different genera and might work as a bridge between early and late colonizers (Andersen et al. 1998; Souto and Colombo 2008b). Previous studies have demonstrated that $F$. nucleatum utilizes the surface protein RadD to bind and form a dual-species biofilm with other oral species (Park et al. 2016; Lima et al. 2017). Moreover, Da Silva-Boghossian et al. (2011) demonstrated that 
Table 2 Interactions between non-oral bacteria and oral microorganisms in the oral cavity

\begin{tabular}{|c|c|c|c|}
\hline Non-oral bacteria & Oral bacteria & Type of interaction & References $^{\mathrm{a}}$ \\
\hline P. aeruginosa & A. viscosus & Coaggregation & Komiyama and Gibbons (1984) \\
\hline P. aeruginosa & $\begin{array}{l}\text { S. sanguis, } S . \text { mitis } \\
\text { A. naeslundii }\end{array}$ & & Komiyama et al. (1987) \\
\hline S. aureus & F. nucleatum & & Tawara et al.(1996) \\
\hline H. pylori & Fusobacterium & & Andersen et al. (1998) \\
\hline GNRs & P. gingivalis, T. forsythia & & Socransky et al. (1998) \\
\hline S. aureus & $\begin{array}{l}\text { A. Naeslundii } \\
\text { A. viscosus } \\
\text { P. gingivalis }\end{array}$ & & Kamaguchi et al. (2003) \\
\hline Weissella cibaria & F. nucleatum & & Kang et al. (2005) \\
\hline E. faecalis & F. nucleatum & & Johnson et al. (2006) \\
\hline GNRs & P. gingivalis & & Ardila et al. (2011) \\
\hline A. baumannii & T. forsythia, $P$. gingivalis, T.denticola & & Da Silva-Boghossian et al. (2011) \\
\hline \multicolumn{4}{|l|}{ P. aeruginosa } \\
\hline GNRs & A. actinomycetemcomitans & & Ardila et al. (2012) \\
\hline S. aureus & F. nucleatum, $P$. gingivalis & & Lima et al. (2019) \\
\hline S. aureus & Viridans group streptococci & & Uehara et al. (2001) \\
\hline H. pylori & $\begin{array}{l}\text { S. oralis } \\
\text { S. mutans } \\
\text { S. sobrinus } \\
\text { A. naeslundii } \\
\text { P. intermedia } \\
\text { P. nigrescens }\end{array}$ & Antagonistic relationship & Okuda et al. (2003) \\
\hline $\begin{array}{l}\text { P. aeruginosa } \\
\text { A. baumannii }\end{array}$ & S. sanguinis & & Watanabe et al. (2009) \\
\hline $\begin{array}{l}\text { E. faecalis } \\
\text { S. aureus }\end{array}$ & A. actinomycetemcomitans & & Da Silva-Boghossian et al. (2011) \\
\hline P. aeruginosa & $\begin{array}{l}\text { S. parasanguinis } \\
\text { S. sanguinis } \\
\text { S. gordonii }\end{array}$ & & Scoffield and Wu. (2015) \\
\hline E. faecalis & S. oris, S. mutans & & Thurnheer and Belibasakis (2015) \\
\hline
\end{tabular}

$P$. aeruginosa seemed to have synergism with $A$. actinomycetemcomitans, raising the risk of periodontal disease. Nonetheless, in the same study, the presence of E. faecalis, or $S$. aureus in association with $A$. actinomycetemcomitans decreased the risk of periodontal disease. However, other studies have revealed that $S$. aureus and E. faecalis were detected at higher levels and with greater prevalence in periodontitis than the non-periodontitis subjects (Fritschi et al. 2008; Persson et al. 2008). The differences in methods of detection and ecological variables may account for the data variability amongst these studies.

Antagonistic relationships are also detected in such intricate microbial communities. Nutritional competition between two early colonizers of the oral cavity and $E$. faecalis was observed. It was shown that the presence of $E$. faecalis in the oral plaque causes a significant reduction in the numbers of Streptococcus oralis and Streptococcus mutans (Thurnheer and Belibasakis 2015), which is in line with other studies demonstrating that E. faecalis dominates numerically over $S$. mutans in dual-species biofilms (Deng et al. 2009; Li et al. 2014).

Moreover, Okuda et al. (2003) found that Streptococcus oralis, Actinomyces naeslundii, Streptococcus mutans, Prevotella intermedia, Prevotella nigrescens, and Streptococcus sobrinus, produce bacteriocin-like inhibitory proteins against $H$. pylori. The fact that subjects with good oral hygiene harbor less $H$. pylori in their mouths could also be due to the inhibitory activity of the early colonizers of dental biofilms, such as oral streptococci, over that species (Anderson et al. 1998). Likewise, Watanabe et al. (2009) demonstrated that a substance called the "new-antipseudomonal substance", derived from Streptococcus sanguinis could have bactericidal activity against $A$. baumannii and $P$. aeruginosa. Nevertheless, these complex and dynamic interactions remain unknown. More profound studies focusing mainly on quorum sensing are needed to understand how non-oral bacteria regulate their genes and coordinate cooperative behaviors in the presence of oral bacteria. 


\section{Conclusion and future outlooks}

The complex and dynamic interactions in the oral ecosystem between oral and non-oral bacteria are far from being wholly unraveled, and the pathogenetic mechanisms used by these microorganisms are still unclear. Nevertheless, it is clear that non-oral bacteria are not passive bystanders and could play an essential role in oral and systemic diseases. Some non-oral bacteria, such as those covered by this review, are becoming major microbes in the oral cavity and they are increasingly isolated from healthy subjects.

This review highlighted the possible role, versatility, and pathogenic potential of non-oral bacteria in the oral cavity. However, some studies that were used displayed some limitations. Most of the studies available on this subject were cross-sectional studies. Longitudinal studies are also needed to track the presence of these bacteria over an extended period. Assessing quantitatively, the presence of non-oral bacteria is of utmost importance and not just counting on presence/absence. Furthermore, molecular biology methods are also needed to see whether non-oral bacteria are genetically different from isolates from other parts of the human body.

Despite the limitations, the presence of non-oral bacteria in the oral cavity is clearly worrisome. It needs more attention to broaden our understanding of the oral ecosystem and develop novel and more adequate preventive and therapeutic approaches, as well as diagnostic applications so that we can control the spread of non-oral bacteria and render them incapable of damaging the host.

Supplementary Information The online version contains supplementary material available at https://doi.org/10.1007/s00203-021-02300-y.

Author's contributions NZ conceptualized and wrote this article.

Funding This work received no external funding.

\section{Declarations}

Conflict of interest The author declares no conflict of interest.

\section{References}

Agarwal S, Jithendra KD (2012) Presence of Helicobacter pylori in subgingival plaque of periodontitis patients with and without dyspepsia, detected by polymerase chain reaction and culture. $\mathrm{J}$ Indian Soc Periodontol 16(3):398-403. https://doi.org/10.4103/ 0972-124X.100919

Agwu E, Ihongbe JC, Ezeonwumelu JO, Lodhi MM (2015) Baseline burden and antimicrobial susceptibility of pathogenic bacteria recovered from oral lesions of patients with HIV/AIDS in SouthWestern Uganda. Oral Sci Int 12(2):59-66
Al-Ahmad A, Müller N, Müller N, Wiedmann-Al-Ahmad M, Hellwig E (2009) Endodontic and salivary isolates of Enterococcus faecalis integrate into biofilm from human salivary bacteria cultivated in vitro. J Endod 35(7):986-991. https://doi.org/10. 1016/j.joen.2009.04.013

Al-Ahmad A, Ameen H, Pelz K, Karygianni L, Wittmer A, Hellwig E (2014) Antibiotic resistance and capacity for biofilm formation of different bacteria isolated from endodontic infections associated with root-filled teeth. J Endod 40(2):223-230. https://doi.org/10.1016/j.joen.2013.07.023

Al-Hebshi NN, Nasher AT, Maryoud MY, Homeida HE, Chen T, Idris AM, Johnson NW (2017) Inflammatory bacteriome featuring Fusobacterium nucleatum and Pseudomonas aeruginosa identified in association with oral squamous cell carcinoma. Sci Rep 7(1):1834. https://doi.org/10.1038/s41598-017-02079-3

Ali RW, Velcescu C, Jivanescu MC, Lofthus B, Skaug N (1996) Prevalence of 6 putative periodontal pathogens in subgingival plaque samples from Romanian adult periodontitis patients. J Clin Periodontol 23(2):133-139. https://doi.org/10.1111/j. 1600-051x.1996.tb00546.x

Almståhl A, Wikström M, Kroneld U (2001) Microflora in oral ecosystems in primary Sjögren's syndrome. J Rheumatol 28(5):1007-1013

Almståhl A, Wikström M, Fagerberg-Mohlin B (2008) Microflora in oral ecosystems in subjects with radiation-induced hyposalivation. Oral Dis 14(6):541-549. https://doi.org/10.1111/j. 1601-0825.2007.01416.x

Andersen RN, Ganeshkumar N, Kolenbrander PE (1998) Helicobacter pylori adheres selectively to Fusobacterium spp. Oral Microbiol Immunol 13(1):51-54. https://doi.org/10.1111/j. 1399-302x.1998.tb00751.x

Anderson AC, Jonas D, Huber I (2016) Enterococcus faecalis from food, clinical specimens, and oral sites: prevalence of virulence factors in association with biofilm formation. Front Microbiol 6:1534. https://doi.org/10.3389/fmicb.2015.01534

Ardila CM, López MA, Guzmán IC (2011) Positive correlations between presence of gram negative enteric rods and Porphyromonas gingivalis in subgingival plaque. Acta Odontol Latinoam 24(1): 15-19

Ardila CM, Alzate J, Guzmán IC (2012) Relationship between Gram negative enteric rods, Aggregatibacter actinomycetemcomitans, and clinical parameters in periodontal disease. J Indian Soc Periodontol 16:65-69. https://doi.org/10.4103/0972-124X. 94607

Arirachakaran P, Poovorawan Y, Dahlén G (2016) Highly-active antiretroviral therapy and oral opportunistic microorganisms in HIV-positive individuals of Thailand. J Investig Clin Dent 7(2):158-167. https://doi.org/10.1111/jicd.12142

Arirachakaran P, Luangworakhun S, Charalampakis G, Dahlén G (2019) Non-oral, aerobic, Gram-negative bacilli in the oral cavity of Thai HIV-positive patients on Highly-active anti-retrovirus therapy medication. J Investig Clin Dent 10(2):e12387. https:// doi.org/10.1111/jicd.12387

Back-Brito GN, El Ackhar VNR, Querido SMR, dos Santos SSF, Jorge, A.... Koga-Ito, C. Y, (2011) Staphylococcus spp., Enterobacteriaceae and Pseudomonadaceae oral isolates from Brazilian HIV-positive patients. Correlation with CD4 cell counts and viral load. Arch Oral Biol 56:1041-1046. https://doi.org/10.1016/j. archoralbio.2011.02.016

Barbosa FC, Mayer MP, Saba-Chujfi E, Cai S (2001) Subgingival occurrence and antimicrobial susceptibility of enteric rods and pseudomonads from Brazilian periodontitis patients. Oral Microbiol Immunol 16(5):306-310. https://doi.org/10.1034/j. 1399-302x.2001.016005306.x

Beatty AL, Malloy JL, Wright JR (2005) Pseudomonas aeruginosa degrades pulmonary surfactant and increases conversion 
in vitro. Am J Respir Cell Mol Biol 32(2):128-134. https://doi. org/10.1165/rcmb.2004-0276OC

Blomqvist S, Leonhardt Å, Arirachakaran P, Carlen A, Dahlén G (2015) Phenotype, genotype, and antibiotic susceptibility of Swedish and Thai oral isolates of Staphylococcus aureus. J Oral Microbiol 7:26250. https://doi.org/10.3402/jom.v7.26250

Botero JE, Contreras A, Lafaurie G, Jaramillo A, Betancourt M, Arce RM (2007a) Occurrence of periodontopathic and superinfecting bacteria in chronic and aggressive periodontitis subjects in a Colombian population. J Periodontol 78(4):696-704. https:// doi.org/10.1902/jop.2007.060129

Botero JE, Arce RM, Escudero M, Betancourth M, Jaramillo A, Contreras A (2007b) Frequency of detection of periodontopathic and superinfecting bacteria in HIV-positive patients with periodontitis. J Int Acad Periodontol 9(1):13-18

Carmona IT, Diz Dios P, Scully C (2002) An update on the controversies in bacterial endocarditis of oral origin. Oral Surg Oral Med Oral Pathol Oral Radiol Endod 93(6):660-670. https:// doi.org/10.1067/moe.2002.122338

Chinnasamy A, Ramalingam K, Chopra P, Gopinath V, Bishnoi G-P, Chawla G (2019) Chronic nail biting, orthodontic treatment and Enterobacteriaceae in the oral cavity. J Clin Exp Dent 11:e1157-e1162. https://doi.org/10.4317/jced.56059

Cole MF, Bryan S, Evans MK, Pearce CL, Sheridan MJ, Sura PA, Wientzen RL, Bowden GH (1999) Humoral immunity to commensal oral bacteria in human infants : salivary secretory immunoglobulin A antibodies reactive with Streptococcus mitis biovar 1, Streptococcus oralis, Streptococcus mutans, and Enterococcus faecalis during the first two years of life. Infect Immun 67(4):1878-1886

Colombo AP, Haffajee AD, Dewhirst FE (1998) Clinical and microbiological features of refractory periodontitis subjects. J Clin Periodontol 25(2):169-180. https://doi.org/10.1111/j.1600051x.1998.tb02424.x

Craig SJC, Blankenberg D, Parodi ACL (2018) Child weight gain trajectories linked to oral microbiota composition. Sci Rep 8(1):14030. https://doi.org/10.1038/s41598-018-31866-9

Cuesta Ai VJ, MiMlAc BNR (2010) Prevalence of Staphylococcus spp and Candida spp in the oral cavity and periodontal pockets of periodontal disease patients. Acta Odontol Latinoam 23:20-26

Da Silva-Boghossian CM, do Souto RM, Luiz RR, Colombo AP (2011) Association of red complex, A. actinomycetemcomitans and non-oral bacteria with periodontal diseases. Arch Oral Biol 56(9):899-906

Da Silva-Boghossian CM, Neves AB, Resende FAR, Colombo APV (2013) Suppuration-associated bacteria in patients with chronic and aggressive periodontitis. J Periodontol 84(9):e9-e16. https:// doi.org/10.1902/jop.2013.120639

Dahlén G (2009) Bacterial infections of the oral mucosa. Periodontol 2000 49:13-38. https://doi.org/10.1111/j.1600-0757.2008. 00295.x

Dahlén G, Wikström M (1995) Occurrence of enteric rods, staphylococci and Candida in subgingival samples. Oral Microbiol Immunol 10(1):42-46. https://doi.org/10.1111/j.1399-302x. 1995.tb00116.x

Deng DM, Hoogenkamp MA, Exterkate RAM, Jiang LM, van der Sluis, Crielaard W (2009) Influence of Streptococcus mutans on Enterococcus faecalis biofilm formation. J Endod 35:1249-1252. https://doi.org/10.1016/j.joen.2009.05.038

Dewhirst FE, Chen T, Izard J, Paster BJ, Tanner ACR, Wade WG (2010) The human oral microbiome. J Bacteriol. 192(19):5002-5017

Edwardsson S, Bing M, Axtelius B, Lindberg B, Söderfeldt B, Attström $R$ (1999) The microbiota of periodontal pockets with different depths in therapy-resistant periodontitis. J Clin Periodontol 26(3):143-152
Ewan VC, Sails AD, Walls AWG, Rushton S, Newton JL (2015) Dental and microbiological risk factors for hospital-acquired pneumonia in non-ventilated older patients. PLoS One 10:e0123622. https:// doi.org/10.1371/journal.pone.0123622

Fritschi BZ, Albert-Kiszely A, Persson GR (2008) Staphylococcus aureus and other bacteria in untreated periodontitis. J Dent Res 87(6):589-593. https://doi.org/10.1177/154405910808700605

Gao L, Xu T, Huang G, Jiang S, GuChen YF (2018) Oral microbiomes : more and more importance in oral cavity and whole body. Protein Cell 9(5):488-500. https://doi.org/10.1007/s13238-018-0548-1

Ghapanchi J, Emami A, Rezazadeh F, Shakibasefat H, Pirbonyeh N (2019) Isolation of Enterococcus faecalis in the saliva samples of patient candidates for liver transplantation. J Dent Res 16(5):333-337

Gibson J, Wray D, Bagg J (2000) Oral staphylococcal mucositis. Oral Surg Oral Med Oral Pathol Oral Radiol Endod 89(2):171-176. https://doi.org/10.1067/moe.2000.101810

Gonçalves LS, Soares FSM, Souza CO, Souto R, Colombo AP (2007a) Clinical and microbiological profiles of human immunodeficiency virus (HIV)-seropositive Brazilians undergoing highly active antiretroviral therapy and HIV-seronegative Brazilians with chronic periodontitis. J Periodontol 78(1):87-96. https:// doi.org/10.1902/jop.2007.060040

Gonçalves MO, Coutinho-Filho WP, Pimenta FP, Pereira GA, MattosGuaraldi AL, Hirata R (2007b) Periodontal disease as reservoir for multi-resistant and hydrolytic enterobacterial species. Lett Appl Microbiol 44(5):488-494. https://doi.org/10.1111/j.1472765X.2007.02111.x

Gosney M, Punekar S, Playfer JR, Bilsborrow PK, Martin MV (2003) The incidence of oral Gram-negative bacteria in patients with Parkinson's disease. Eur J Intern Med 14(8):484-487. https:// doi.org/10.1016/j.ejim.2003.09.009

Handal T, Caugant DA, Olsen I (2003) Antibiotic resistance in bacteria isolated from subgingival plaque in a Norwegian population with refractory marginal periodontitis. Antimicrob Agents Chemother 47(4):1443-1446. https://doi.org/10.1128/aac.47.4. 1443-1446.2003

Jackson MS, Bagg J, Gupta MN, Sturrock RD (1999) Oral carriage of staphylococci in patients with rheumatoid arthritis. Rheumatology 38(6):572-575. https://doi.org/10.1093/rheumatology/38.6. 572

Jacobson JJ, Patel B, Asher G, Woolliscroft JO, Schaberg D (1997) Oral Staphylococcus in older subjects with rheumatoid arthritis. J Am Geriatr Soc 45(5):590-593. https://doi.org/10.1111/j.15325415.1997.tb03092.x

Johnson EM, Flannagan SE, Sedgley CM (2006) Coaggregation interactions between oral and endodontic Enterococcus faecalis and bacterial species isolated from persistent apical periodontitis. J Endod 32(10):946-950. https://doi.org/10.1016/j.joen.2006.03. 023

Kamaguchi A, Nakayama K, Ichiyama S, Nakamura R, Watanabe T, Ohyama T (2003) Effect of Porphyromonas gingivalis vesicles on coaggregation of Staphylococcus aureus to oral microorganisms. Curr Microbiol 47(12):485-91. https://doi.org/10.1007/ s00284-003-4069-6

Kang MS, Na HS, Oh JS (2005) Coaggregation ability of Weissella cibaria isolates with Fusobacterium nucleatum and their adhesiveness to epithelial cells. FEMS Microbiol Lett 253(2):323329. https://doi.org/10.1016/j.femsle.2005.10.002

Kart D, Yabanoglu Ciftci S, Nemutlu E (2020) Altered metabolomic profile of dual-species biofilm: Interactions between Proteus mirabilis and Candida albicans. Microbiol Res 230:126346. https://doi.org/10.1016/j.micres.2019.126346

Kayaoglu G, Ørstavik D (2004) Virulence factors of Enterococcus faecalis: relationship to endodontic disease. Crit Rev Oral Biol Med 15(5):308-320. https://doi.org/10.1177/154411130401500506 
Kazemian H, Bourbour S, Beheshti M, Bahador A (2017) Oral colonization by nosocomial pathogens during hospitalization in intensive care unit and prevention strategies. Recent Pat Antiinfect Drug Discov 12(1):8-20. https://doi.org/10.2174/1574891X12 666170215152854

Kearney A, Kinnevey P, Shore A (2020) The oral cavity revealed as a significant reservoir of Staphylococcus aureus in an acute hospital by extensive patient, healthcare worker and environmental sampling. J Hosp Infect S0195-6701(20):30103-30111. https:// doi.org/10.1016/j.jhin.2020.03.004

Kolenbrander PE (2000) Oral microbial communities: biofilms, interactions, and genetic systems. Annu Rev Microbiol 54:413-437. https://doi.org/10.1146/annurev.micro.54.1.413

Kolenbrander PE, Palmer RJ, Periasamy S, Jakubovics NS (2010) Oral multispecies biofilm development and the key role of cell-cell distance. Nat Rev Microbiol 8(7):471-480. https://doi.org/10. 1038/nrmicro2381

Komiyama K, Gibbons RJ (1984) Interbacterial adherence between Actinomyces viscosus and strains of Streptococcus pyogenes, Streptococcus agalactiae, and Pseudomonas aeruginosa. Infect Immun 44(1):86-90

Komiyama K, Tynan JJ, Habbick BF, Duncan DE, Liepert DJ (1985) Pseudomonas aeruginosa in the oral cavity and sputum of patients with cystic fibrosis. Oral Surg Oral Med Oral Pathol 59:590-594. https://doi.org/10.1016/0030-4220(85)90187-2

Komiyama K, Habbick BF, Gibbons RJ (1987) Interbacterial adhesion between Pseudomonas aeruginosa and indigenous oral bacteria isolated from patients with cystic fibrosis. Can J Microbiol 33(1):27-32. https://doi.org/10.1139/m87-005

Komiyama EY, Lepesqueur LSS, Yassuda CG, Samaranayake LP, Parahitiyawa NB, Balducci I, Koga-Ito CY (2016) Enterococcus species in the oral cavity : prevalence, virulence factors and antimicrobial susceptibility. PLoS One 11(9):e0163001. https:// doi.org/10.1371/journal.pone.0163001

Kouidhi B, Zmantar T, Mahdouani K, Hentati H, Bakhrouf A (2011) Antibiotic resistance and adhesion properties of oral Enterococci associated to dental caries. BMC Microbiol 11:155. https://doi. org/10.1186/1471-2180-11-155

Kreth J, Merritt J, Qi F (2009) Bacterial and host interactions of oral streptococci. DNA Cell Biol 28(8):397-403. https://doi.org/10. 1089/dna.2009.0868

Leão-Vasconcelos LS, Lima AB, Costa DM (2015) Enterobacteriaceae isolates from the oral cavity of workers in a Brazilian oncology hospital. Rev Inst Med Trop Sao Paulo 57(2):121-127. https:// doi.org/10.1590/S0036-46652015000200004

Lee YT, Fung CP, Wang FD, Chen CP, Chen TL, Cho WL (2012) Outbreak of imipenem-resistant Acinetobacter calcoaceticusAcinetobacter baumannii complex harboring different carbapenemase gene-associated genetic structures in an intensive care unit. J Microbiol Immunol Infect 45(1):43-51. https://doi.org/ 10.1016/j.jmii.2011.09.020

Li X, Hoogenkamp MA, Ling J, Crielaard W, Deng DM (2014) Diversity of Streptococcus mutans strains in bacterial interspecies interactions. J Basic Microbiol 54(2):97-103. https://doi.org/ 10.1002/jobm.201200457

Lima BP, Shi W, Lux R (2017) Identification and characterization of a novel Fusobacterium nucleatum adhesin involved in physical interaction and biofilm formation with Streptococcus gordonii. Microbiologyopen 6(3):e00444. https://doi.org/10.1002/mbo3. 444

Lima BP, Hu LI, Vreeman GW, Weibel DB, Lux R (2019) The oral bacterium Fusobacterium nucleatum binds Staphylococcus aureus and alters expression of the staphylococcal accessory regulator sarA. Microb Ecol 78(2):336-347. https://doi.org/10.1007/ s00248-018-1291-0
Lins RX, Hirata R, Wilson M, Lewis MAO, Fidel RAS, Williams D (2019) Comparison of genotypes, antimicrobial resistance and virulence profiles of oral and non oral Enterococcus faecalis from Brazil, Japan and the United Kingdom. J Dent 84:49-54. https://doi.org/10.1016/j.jdent.2019.03.002

Listgarten MA, Lai CH, Lai CH (1999) Comparative microbiological characteristics of failing implants and periodontally diseased teeth. J Periodontol 70(4):431-437. https://doi.org/10.1902/jop. 1999.70.4.431

Livermore DM (2002) Multiple mechanisms of antimicrobial resistance in Pseudomonas aeruginosa: our worst nightmare? Clin Infect Dis 34(5):634-640. https://doi.org/10.1086/338782

Lowy FD (1998) Staphylococcus aureus infections. N Engl J Med 339(8):520-532. https://doi.org/10.1056/NEJM19980820339 0806

Mahasneh SA, Mahasneh AM (2017) Probiotics: a promising role in dental health. J Dent 5(4):26. https://doi.org/10.3390/dj5040026

Martínez-Lamas L, Constenla-Caramés L, Otero-Fernández S, Álvarez-Fernández M (2014) New clone of ST-187 Acinetobacter baumannii responsible for an outbreak in an intensive care unit. Enferm Infecc Microbiol Clin 32(4):242-245. https://doi.org/10. 1016/j.eimc.2013.10.014

Martínez-Pabón MC, Isaza-Guzmán DM, Mira-López NR, GarcíaVélez C, Tobón-Arroyave SI (2010) Screening for subgingival occurrence of gram-negative enteric rods in periodontally diseased and healthy subjects. Arch Oral Biol 55(10):728-736. https://doi.org/10.1016/j.archoralbio.2010.07.008

Merghni A, Ben Nejma M, Hentati H, Mahjoub A, Mastouri M (2014) Adhesive properties and extracellular enzymatic activity of Staphylococcus aureus strains isolated from oral cavity. Microb Pathog 73:7-12. https://doi.org/10.1016/j.micpath.2014.05.002

Merghni A, Ben Nejma M, Helali I, Hentati H, Bongiovanni A, Mastouri M (2015) Assessment of adhesion, invasion and cytotoxicity potential of oral Staphylococcus aureus strains. Microb Pathog 86:1-9. https://doi.org/10.1016/j.micpath.2015.05.010

Nakou M, Kamma J, Gargalianos P, Laskaris G, Mitsis F (1997) Periodontal microflora of HIV infected patients with periodontitis. Anaerobe 3(2-3):97-102. https://doi.org/10.1006/anae.1997. 0081

Okuda K, Kimizuka R, Katakura A, Nakagawa T, Ishihara K (2003) Ecological and immunopathological implications of oral bacteria in Helicobacter pylori infected disease. J Periodontol 74(1):123128. https://doi.org/10.1902/jop.2003.74.1.123

Okui A, Soga Y, Kokeguchi S, Nose M, Yamanaka R, Kusano N, Morita M (2015) Detection of identical isolates of Enterococcus faecalis from the blood and oral mucosa in a patient with infective endocarditis. Intern Med J 54(14):1809-1814. https:// doi.org/10.2169/internalmedicine.54.3223

Panghal M, Kaushal V, Yadav JP (2011) In vitro antimicrobial activity of ten medicinal plants against clinical isolates of oral cancer cases. Ann Clin Microbiol Antimicrob 10:21. https://doi.org/10. 1186/1476-0711-10-21

Park J, Shokeen B, Haake SK, Lux R (2016) Characterization of Fusobacterium nucleatum ATCC 23726 adhesins involved in strainspecific attachment to Porphyromonas gingivalis. Int J Oral Sci 8(3):138-144

Pereira CA, Toledo BC, Santos CT, Pereira Costa ACB, Back-Brito GN, Jorge AOC (2013) Opportunistic microorganisms in individuals with lesions of denture stomatitis. Diagn Microbiol Infect Dis 76(4):419-424. https://doi.org/10.1016/j.diagmicrobio.2013. 05.001

Persson GR, Renvert S (2014) Cluster of bacteria associated with periimplantitis. Clin Implant Dent Relat Res 16(6):783-793. https:// doi.org/10.1111/cid.12052

Persson GR, Hitti J, Paul K, Hirschi R, Weibel M, Rothen M, Persson RE (2008) Tannerella forsythia and Pseudomonas aeruginosa 
in subgingival bacterial samples from parous women. J Periodontol 79(3):508-516. https://doi.org/10.1902/jop.2008. 070350

Pihl M, Chávez de Paz LE, Schmidtchen A, Svensäter G, Davies JR (2010) Effects of clinical isolates of Pseudomonas aeruginosa on Staphylococcus epidermidis biofilm formation. FEMS Immunol Med Microbiol 59(3):504-512. https://doi.org/10.1111/j.1574695X.2010.00707.x

Priyadharsini VJ, Smiline Girija AS, Paramasivam A (2018) In silico analysis of virulence genes in an emerging dental pathogen $A$. baumannii and related species. Arch Oral Biol 94:93-98. https:// doi.org/10.1016/j.archoralbio.2018.07.001

Rams TE, Andriolo M, Feik D, Abel SN, McGivern TM, Slots J (1991) Microbiological study of HIV-related periodontitis. J Periodontol 62(1):74-81. https://doi.org/10.1902/jop.1991.62.1.74

Ranganathan AT, Sarathy S, Chandran CR, Iyan K (2017) Subgingival prevalence rate of enteric rods in subjects with periodontal health and disease. J Indian Soc Periodontol 21(3):224-228. https://doi. org/10.4103/jisp.jisp_204_17

Richards AM, Abu Kwaik Y, Lamont RJ (2015) Code blue: Acinetobacter baumannii, a nosocomial pathogen with a role in the oral cavity. Mol Oral Microbiol 30(1):2-15. https://doi.org/10. 1111/omi.12072

Rivas Caldas R, Le Gall F, Revert K, Rault G, Virmaux Boisramé MS (2015) Pseudomonas aeruginosa and periodontal pathogens in the oral cavity and lungs of cystic fibrosis patients : a casecontrol study. J Clin Microbiol 53(6):1898-1907. https://doi.org/ 10.1128/JCM.00368-15

Scannapieco FA, Yu J, Raghavendran K, Vacanti A, Owens SI, Mylotte JM (2009) A randomized trial of chlorhexidine gluconate on oral bacterial pathogens in mechanically ventilated patients. Crit Care 13(4):R117. https://doi.org/10.1186/cc7967

Scoffield JA, Wu H (2015) Oral streptococci and nitrite-mediated interference of Pseudomonas aeruginosa. Infect Immun 83(1):101107. https://doi.org/10.1128/IAI.02396-14

Sedgley CM, Lennan SL, Clewell DB (2004) Prevalence, phenotype and genotype of oral enterococci. Oral Microbiol Immunol 19(2):95-101. https://doi.org/10.1111/j.0902-0055.2004.00122.x

Sedgley CM, Lennan SL, Appelbe OK (2005) Survival of Enterococcus faecalis in root canals ex vivo. Int Endod J 38(10):735-742. https://doi.org/10.1111/j.1365-2591.2005.01009.x

Sedgley C, Buck G, Appelbe O (2006) Prevalence of Enterococcus faecalis at multiple oral sites in endodontic patients using culture and PCR. J Endod 32(2):104-109. https://doi.org/10.1016/j.joen. 2005.10.022

Simões-Silva L, Ferreira S, Santos-Araujo C (2018) Oral Colonization of Staphylococcus species in a peritoneal dialysis population: a possible reservoir for PD-related infections? Can J Infect Dis Med Microbiol 2018:5789094. https://doi.org/10.1155/2018/ 5789094

Slots J, Rams TE, Schonfeld SE (1991) In vitro activity of chlorhexidine against enteric rods, pseudomonas and acinetobacter from human periodontitis. Oral Microbiol Immunol 6(1):62-64. https://doi.org/10.1111/j.1399-302x.1991.tb00452.x

Smith RS, Iglewski BH (2003) $P$. aeruginosa quorum-sensing systems and virulence. Curr Opin Microbiol 6(1):56-60. https://doi.org/ 10.1016/s1369-5274(03)00008-0

Smith AJ, Jackson MS, Bagg J (2001) The ecology of Staphylococcus species in the oral cavity. J Med Microbiol 50(11):940-946. https://doi.org/10.1099/0022-1317-50-11-940

Smith AJ, Brewer A, Kirkpatrick P, Jackson MS, Young J, Watson S, Thakker B (2003) Staphylococcal species in the oral cavity from patients in a regional burns unit. J Hosp Infect 55(3):184-189. https://doi.org/10.1016/j.jhin.2003.08.004

Socransky SS, Haffajee AD, Cugini MA, Smith C, Kent RL (1998) Microbial complexes in subgingival plaque. J Clin Periodontol
25(2):134-144. https://doi.org/10.1111/j.1600-051x.1998.tb024 19.x

Soni P, Parihar RS, Soni LK (2017) Opportunistic microorganisms in oral cavity according to treatment status in head and neck cancer patients. J Clin Diagn Res 11(9):DC14-DC17. https://doi.org/10. 7860/JCDR/2017/27284.10635

Souto R, Colombo APV (2008a) Prevalence of Enterococcus faecalis in subgingival biofilm and saliva of subjects with chronic periodontal infection. Arch Oral Biol 53(2):155-160. https://doi.org/ 10.1016/j.archoralbio.2007.08.004

Souto R, Colombo APV (2008b) Detection of Helicobacter pylori by polymerase chain reaction in the subgingival biofilm and saliva of non-dyspeptic periodontal patients. J Periodontol 79(1):97103. https://doi.org/10.1902/jop.2008.070241

Souto R, de Andrade AFB, Uzeda M, Colombo APV (2006) Prevalence of non-oral pathogenic bacteria in subgingival biofilm of subjects with chronic periodontitis. Braz J Microbiol 37(3):208-215. https://doi.org/10.1590/S1517-83822006000300002

Souto R, Silva-Boghossian CM, Colombo APV (2014) Prevalence of Pseudomonas aeruginosa and Acinetobacter spp In subgingival biofilm and saliva of subjects with chronic periodontal infection. Braz. J. Microbiol 45(2):495-501. https://doi.org/10.1590/ S1517-83822014000200017

Souza LCD, Lopes FF, Bastos EG, Alves MC (2018) Oral infection by Pseudomonas aeruginosa in patient with chronic kidney disease a case report. J Bras Nefrol 40(1):82-85. https://doi.org/10.1590/ $1678-4685-J B N-3812$

Tada A, Hanada N (2010) Opportunistic respiratory pathogens in the oral cavity of the elderly. FEMS Immunol Med Microbiol 60(1):1-17. https://doi.org/10.1111/j.1574-695X.2010.00709.x

Tawara Y, Honma K, Naito Y (1996) Methicillin-resistant Staphylococcus aureus and Candida albicans on denture surfaces. Bull Tokyo Dent Coll 37(3):119-128

Thurnheer T, Belibasakis GN (2015) Integration of non-oral bacteria into in vitro oral biofilms. Virulence 6(3):258-264. https://doi. org/10.4161/21505594.2014.967608

Uehara Y, Kikuchi K, Nakamura T (2001) Inhibition of methicillinresistant Staphylococcus aureus colonization of oral cavities in newborns by viridans group streptococci. Clin Infect Dis 32(10):1399-1407. https://doi.org/10.1086/320147

Van Winkelhoff AJ, Rurenga P, Wekema-Mulder GJ, Singadji ZM, Rams TE (2016) Non-oral gram-negative facultative rods in chronic periodontitis microbiota. Microb Pathog 94:117-122. https://doi.org/10.1016/j.micpath.2016.01.020

Vidana R, Sullivan A, Billström H, Ahlquist M, Lund B (2011) Enterococcus faecalis infection in root canals-host-derived or exogenous source? Lett Appl Microbiol 52(2):109-115. https://doi org/10.1111/j.1472-765X.2010.02972.x

Vieira Colombo AP, Magalhães CB, Hartenbach FARR, Martins do SoutoMaciel da Silva-Boghossian RC (2016) Periodontal-disease-associated biofilm : a reservoir for pathogens of medical importance. Microb Pathog 94:27-34. https://doi.org/10.1016/j. micpath.2015.09.009

Wade WG (2013) The oral microbiome in health and disease. Pharmacol Res 69(1):137-143. https://doi.org/10.1016/j.phrs.2012. 11.006

Wang L, Dong M, Zheng J, Song Q, Yin W, Li J, Niu W (2011) Relationship of biofilm formation and gelE gene expression in Enterococcus faecalis recovered from root canals in patients requiring endodontic retreatment. J Endod 37(5):631-636. https://doi.org/ 10.1016/j.joen.2011.02.006

Watanabe K, Senba M, Ichinose A, Yamamoto T, Ariyoshi K, Matsumoto K (2009) Bactericidal activity in filtrated supernatant of Streptococcus sanguinis against multidrug-resistant Pseudomonas aeruginosa. Tohoku J Exp Med 219(2):79-84. https:// doi.org/10.1620/tjem.219.79 
World Health Organization (2017) Global priority list of antibioticresistant bacteria to guide research, discovery and development of new antibiotics. https://www.who.int/medicines/publications/ global-priority-list-antibiotic-resistant-bacteria/en/

Yamashita K, Ohara M, Kojima T, Nishimura R, Ogawa T, Hino T et al (2013) Prevalence of drug-resistant opportunistic microorganisms in oral cavity after treatment for oral cancer. J Oral Sci 55(2):145-155

Zarco MF, Vess TJ, Ginsburg GS (2012) The oral microbiome in health and disease and the potential impact on personalized dental medicine. Oral Dis 18(2):109-120. https://doi.org/10.1111/j.16010825.2011.01851.x

Zehnder M, Guggenheim B (2009) The mysterious appearance of enterococci in filled root canals. Int Endod J 42(4):277-287. https:// doi.org/10.1111/j.1365-2591.2008.01537.x

Zhu HW, McMillan AS, McGrath C, Li LSW, Samaranayake LP (2008) Oral carriage of yeasts and coliforms in stroke sufferers: a prospective longitudinal study. Oral Dis 14(1):60-66. https:// doi.org/10.1111/j.1601-0825.2006.01347.x

Zhu X, Wang Q, Zhang C, Cheung GSP, Shen Y (2010) Prevalence, phenotype, and genotype of Enterococcus faecalis isolated from saliva and root canals in patients with persistent apical periodontitis. J Endod 36(12):1950-1955

Zuanazzi D, Souto R, Mattos MBA, Zuanazzi MR, Tura BR, Sansone C, Colombo APV (2010) Prevalence of potential bacterial respiratory pathogens in the oral cavity of hospitalised individuals. Arch Oral Biol 55(1):21-28. https://doi.org/10.1016/j.archo ralbio.2009.10.005

Publisher's Note Springer Nature remains neutral with regard to jurisdictional claims in published maps and institutional affiliations. 